3. What would you suggest as the content for a standard elementary course?

4. What classification of courses in political science would you suggest for the purpose of maintaining unity, and of giving emphasis to fundamental principles?

The committee desires:

a. Comments, suggestions and criticisms of its preliminary recommendations.

b. Specific answers to the above queries by those who have definite convictions as a result of experience.

c. Constructive suggestions for the standardization of elementary courses in political science and for the improvement of instruction in the subject. ${ }^{7}$

Respectfully submitted for the committee by

Charles G. Haines,

Chairman.

\title{
PRELIMINARY REPORT OF THE JOINT COMMITTEE ON ACADEMIC FREEDOM AND ACADEMIC TENURE
}

SUBMITTED IN BEHALF OF THE COMMITTEE BY E. R. A. SELIGMAN

At the December, 1913 meeting of the American Economic Association, the American Sociological Society, and the American Political Science Association, this identical resolution was adopted:

"Resolved, That a committee of three be constituted to examine and report on the present situation in American educational institutions as to liberty of thought, freedom of speech, and security of tenure for teachers of economics (sociology, or political science).

"That the committee be authorized to coöperate with any similar committee that may be constituted by other societies in the field of political and social science."

The three sommittees appointed in virtue of these resolutions subsequently decided to merge into a joint committee on academic freedom, of which Professor Seligman was elected chairman and Professor Lichtenberger secretary. The report herewith presented to each of the three associations is the report of this joint committee.

7 The full report of the committee included a resume of the year's work and a brief statement relative to an investigation of secondary school instruction. Limitations of space required the omission of these portions of the annual report. 
Your committee has held several meetings at which the general problems were discussed and has investigated several cases of alleged infringements of academic freedom. As a result it became apparent that the subject bristled with complexities of such a character that your committee feels itself in a position at present to make only a preliminary report.

It is important at the outset to remove misapprehensions as to the function of the committee. This function, as we understand it, is not that of a merely protective organization or professional trade-union. It was for this very reason that it was made to include publicists and lawyers as well as professors. Its object, as understood by us, is to point out the public rather than the private importance of the problem and to emphasize the duties as well as the rights of all parties concerned.

The public relations of academic freedom, apart from the teachers involved, are fivefold; to science, to the student body, to the trustees, to the presidents, and to the community at large.

(1) The modern university is the chief home of science. The aim of science is to discover new truth, but every new truth means the disappearance of old error and frequently involves a shock to existing opinion. The shock may be unwelcome but unless there be the fullest freedom in scientific investigation and in the proclaiming of its results, there can be no progress.

(2) The student body in our institutions of learning possesses the right of having presented to it the latest results of scientific research, whether or not those results have as yet been firmly incorporated into the body of accepted truth.

(3) The trustees of such institutions are interested in the problem of academic freedom because with the possible conflict in their minds between the claims of the general principle and the immediate welfare of the institutions committed to their charge a clearer understanding of mutual rights and duties should be helpful.

(4) The presidents of our institutions of learning are sometimes in a difficult position because of their double capacity, representing both faculty and trustees. When there is an honest difference of opinion as to the extent and limits of academic freedom it is just as likely that the president may need support against the trustees as that he may act as their mouthpiece in opposition to the faculty.

(5) The community at large has a right to expect of its institutions of learning, whether maintained by public contributions or supported 
by private munificence, the best results of scientific achievement, unhampered by party bias or personal prejudice.

The difficulties of the problem referred to above involve current misunderstandings both as to the nature and limits of academic freedom and as to the fundamental theory of academic tenure of position.

Let us examine first the question of academic freedom or liberty of thought. This problem, it may be stated at the outset, does not exist in colleges under obligations to teach denominationalism, nor in institutions designed to spread specific doctrines of any kind. It is important, however, that such institutions should not be allowed to sail under false colors. Freedom of thought and the inculcation of a particular brand of thought are hopelessly irreconcilable.

If by liberty of thought is meant freedom of research, the necessity of its existence without any limits is so obvious as to be entirely indisputable. So slight, however, is the danger of its infringement in the American institutions of today that this aspect of academic freedom calls for no further discussion.

The situation is different when we come to the other phase of academic freedom, namely, freedom of speech or liberty of expressing in spoken or written word the results of scientific research. In past centuries the chief menace to freedom of this kind was theological; in recent times, with the advent of democracy in politics and industry, the danger zone has been shifted to economics, political, and social science.

The motive for infringing such freedom may be either private or public. In our privately endowed institutions it rarely if ever happens that an attempt is made to limit academic freedom because of threatened injury directly to the individual interests of the authorities. More common is the public or social motive, based on the desire of the authorities to prevent the spread of ideas or influences which are in their opinion harmful to true morals, sound politics, or the real social interests. In between these private and these social motives lies a large field where the motive asserted and believed by the authorities may be social in character and yet where in reality their own interests or that of their friends are implicated. In the political, economic, and social field almost every question, no matter low large and general it at first appears, is more or less affected with private or quasi-private interests; and as the governing body is naturally made up of men who through their standing and ability are personally interested in private enterprises, the points of possible conflict are num- 
berless. When to this is added the consideration that most of the benefactors as well as the parents who send their children to privately endowed institutions themselves belong to the more conservative class, it is apparent that a similar pressure may, however, unconsciously, sometimes be brought to bear upon the academic authorities.

On the other hand, in our state institutions the danger is the reverse. Where the university is dependent for funds upon legislative favor, it has not infrequently happened that the conduct of the institution has been affected by political considerations; and where there is a definite governmental policy or a strong public feeling on economic, social, or political questions, the menace to academic freedom may proceed from the expression of views that in the particular political situation are deemed ultraconservative rather than ultra-radical.

The real point of danger, hence, is not so much the particular shade of opinion as that it differs from the one entertained by the authorities. The problem resolves itself into one of departure from accepted standards; whether the departure is in the one direction or the other is immaterial.

In considering this problem six classes of difficulties present themselves. The first query is as to whether the identical rule ought to be applied to our colleges as to our universities. In a true university there may be a dozen instructors teaching various aspects of the same subject and ranging in their views over the entire gamut of opinion. The student has his choice and balances the idiosyncrasies of one scholar against those of another. In a small college, where there may be only a single instructor to cover the entire field, not only are the students apt to be much more easily influenced in their general point of view, but the reputation of the college itself is more likely to be affected by the opinions of any member of the faculty. There is, indeed, everywhere a danger line; but is the line not somewhat further removed in the one case than in the other?

Secondly, irrespective of the distinction between a college and a university, ought not different rules to be applied to graduate and undergraduate instruction, to teachers of immature, as compared with those of more advanced, students? Is it not true that the more youthful the class of students, the greater is the teacher's obligation to present scientific truths with discretion and with some regard to their character building? Should the rule of academic freedom in all its rigor not be limited to the instructor of the more mature and advanced students, whose character has largely been formed and who are in the proper 
attitude to receive truth for truth's sake? Is not much of the unclearness in the present situation due to the failure to distinguish between classes of instructors?

Thirdly, ought the same rule to apply to the specialist and to the non-specialist? Within the university this problem cannot arise, for the views of a biologist on the tariff or of a physicist on socialism would be of no interest to any of his students. But if the biologist should give a public address on some economic question or if the physicist should take part in a political campaign, ought interference with this to be considered as an infringement of academic freedom?

Fourthly, as to the instructor speaking on his own chosen topic, ought a distinction to be made between the opinions expressed within the class room or lecture hall and those expressed on the outside? The opinions of a scholar in a lecture room indeed ought to be considered privileged. Discussions in the class room are not supposed to be formal utterances for the public at large. They are often designed to provoke opposition or to arouse debate. There should be no room for sensational newspaper quotations from such remarks. In foreign countries it is a misdemeanor to publish or otherwise to quote a university lecturer without his consent. Ought not such a practice to be observed in this country?

The specialist may, however, speak on the subject outside of the class room, either with the students informally or in a scientific address or in a popular talk. He may, in the exercise of the ordinary duties of citizenship, take part in politics, and may even run for office or hold office.

To what extent and under what conditions ought this to be permitted? Does the possession of special opportunities of study and presumably of special knowledge on political, social, or economic questions constitute a reason why one should use his information to influence public opinion? Or does it make it desirable, on the contrary, that he should not voice his opinions? It may be claimed than an academic teacher who publicly takes a definite stand on a political or economic issue is thereby impairing his reputation for impartiality. Does this, however, not exaggerate the distinction between intramural and extramural utterances? If within the class room the scholar discusses a topic in a scientific way, presenting both sides of the question and then drawing his own conclusions, does the mere fact of his expressing these conclusions in public necessarily impair his reputation as a scientist? And has the community not the right to profit by the opinion of the expert, if he really is such? 
Fifthly, to what extent should a scholar be expected to make concessions to public sentiment? That there are limits is obvious. A teacher in a southern university might have private views as to the general philosophy of social equality between the white and the colored races; but would he not be injudicious, to say the least, publicly to oppose the overwhelming general sentiment? A sociologist might come to the conclusion that trial marriages were desirable. But could an objection to the public expression of such views properly be called an infringement of academic freedom? Even though experience shows that there is no man or set of men so capable as to be able to decide what academic teachings shall be suppressed as contrary to good morals, can we claim for the academic teacher a consideration which will entirely relieve him from the consequences applicable to all others when they advance opinions for which the popular mind is not prepared and which are at variance with the recognized fundamental standards?

Sixthly, is not the crux of the situation often to be found less in the statement of any particular opinion than in the method of its expression? If the academic teacher takes part in any discussion where public opinion is sharply divided or hostile, is it not incumbent on him sedulously to refrain from extreme or intemperate statement? Can freedom of speech be permitted to cover self-exploitation or mere desire for notoriety? And if a university teacher differs so widely in method of expression from his fellow scientists as to forfeit their confidence in his scholarship and poise of judgment, can he continue to invoke in his behalf the plea of academic freedom?

It is clear, therefore, there are no rights without duties and that the duties of teacher and of authorities are reciprocal. The duty of the academic authorities is to refrain from confounding their own predilections with what they imagine to be public policy; the duty of the professor is to remember that he is acting not merely as an individual but as the representative of science.

Various kinds of pressure upon a teacher may be exerted to limit his academic freedom, but it is only the most severe and therefore the most unusual that ever come to public notice, namely, dismissal. Milder disciplinary measures are: warning, transfer to other work, denial of promotion or of increase of salary. The difficulty of ascertaining the existence of such measures is almost insurmountable, inasmuch as other reasons may almost always be assigned by the authorities, such as lack of ability, tactlessness, general incompatibility, etc. If, how- 
ever, we confine our attention to dismissal we are brought face to face with the most fundamental point in the problem. What is or what should be the nature of the employment and tenure of a college or university teacher?

On the one hand the view is more or less frankly expressed or implied by the authorities that academic teaching is a purely private employment, resting on a contract between the employing authority and the teacher. The same authority may dismiss the employee at any time, for any cause, or for no assigned cause whatever; and the contract itself is terminable at the pleasure of the trustees. On the other hand, this is denounced as the "hired man" concept of the subject, destructive to the scientific spirit of the work, and to the dignity of the profession necessary to attract able scholars and teachers. Academic teaching, it is said, must be regarded as a quasi-public official employment in which the original appointment is made by the authorities who are bound to act not as private employers or from private motives but as public trustees. It is held that only in this way can there be made possible the development of the standards of disinterested scholarship or can there be created a body of scholars and teachers to perform for the community a necessary function which cannot otherwise be achieved. It is a distinctly different service from that of the judge, the lawyer, the journalist, or the ordinary corporation official. It implies a security of tenure, not as a personal privilege but as an expedient, farsighted public policy, which, so far as it is consistently followed, attracts high ability into a social service with small pecuniary reward.

Evidently the practice in most cases exemplifies neither ideal of employment, although it ranges from the one extreme to the other. In some of the smaller colleges the private-employment concept is nearly realized. In some of the larger universities the public-employment concept is closely approached. Almost everywhere there is great uncertainty of practice, reflecting great vagueness of conviction on the subject.

It is clear that the further we get away from the hired-man theory the more definite will be the replies to the queries which we desire here only to formulate. First, ought an academic teacher ever to be dismissed at all, or ought he to be virtually irremovable, as in the continental universities?

Second, ought a distinction to be drawn in this respect between a college and a university teacher, between an officer of high grade and 
one of low grade; between an officer of long standing and one of recent tenure?

Third, if such a distinction is permissible, ought an academic teacher of long standing ever to be dismissed without the payment of a pension?

Fourth, ought an academic teacher of any grade ever to be summarily dismissed by the authorities without hearing or trial?

Fifth, if there is to be a hearing or trial, ought this to be before the university authorities or before some tribunal representing the general interests of scholarship?

Sixth, ought an academic teacher ever to be dismissed without public declaration of the reasons therefor, and if not, ought the reasons alleged ever to be a mere pretext, even though the suppression of the real reason is in the supposed interest of the individual himself?

From the foregoing it is clear that there may be differences of opinion as to the ideals to be realized, as to the practicable means of attaining the ideal, and as to the limitations to be observed. Our preliminary investigation of actual cases has brought us to the tentative conclusion that mistakes have been made on both sides and that the chief difficulty arises from a failure of academic teachers as well as of academic authorities to observe the duties no less than the rights of their position. In order, therefore, to enable us to devote more study to the investigation, both in its general aspects and in the particular cases of alleged infringement of academic freedom, we recommend that this committee be continued with a view of making a final report at the next annual meeting.

\section{AMERICAN ECONOMIC ASSOCIATION}

Edwin R. A. Seligman, Chairman

Richard T. Ely Frank A. Fetter

AMERICAN POLITICAL SCIENCE ASSOCIATION

F. N. Judson, Chairman

J. Q. Dealey

Herbert Croly

AMERICAN SOCIOLOGICAL SOCIETY

U. G. Weatherly, Chairman

JAMES P. Lichtenberger

Roscoe Pound 